\title{
Prediction and Optimization of Sulphur Trioxide Yield from Calcination of Aluminium Sulfate Using Central Composite Design
}

\author{
Olumide Olu Olubajo ${ }^{1}$, Isa Yusuf Makarfi ${ }^{2}$
}

${ }^{1}$ Abubakar Tafawa Balewa University

Dass road, P. M. B. 0248, Bauchi, 740272, Nigeria

${ }^{2}$ Durban University of Technology

P. 0. Box 1334, Durban, 4000, South Africa

DOI: $10.22178 /$ pos.51-2

LCC Subject Category: QD1-65

Received 28.09.2019

Accepted 28.10.2019

Published online 31.10.2019

Corresponding Author:

Olumide Olu Olubajo

ooolubajo@atbu.edu.ng

(C) 2019 The Authors. This article

is licensed under a Creative

Commons Attribution 4.0 License (c) (i)

\begin{abstract}
Sulphur trioxides are common toxic gaseous pollutants which can be produced from alternative routes via calcination of aluminum sulfate derived from kaolin clay. Its demand increases geometrically, thus the need to optimize the yield of $\mathrm{SO}_{3}$ from the calcination of alum is essential. The rate of alum decomposition was monitored by the formation of $\mathrm{SO}_{3}$ via thermogravimetric analysis and $\mathrm{X}$-ray fluorescence analysis. This study aimed to evaluate the effect of calcination temperature and curing time on the $\mathrm{SO}_{3}$ conversion and yields using Face Central Composite Design and optimize the process conditions to evaluate the maximum yield of $\mathrm{SO}_{3}$ using response surface methodology and its effects and interactions were investigated between $800-$ $900^{\circ} \mathrm{C}$ at $60-180$ minutes. Results indicated that experimental data satisfied second order polynomial regression model for $\mathrm{SO}_{3}$ conversion and $\mathrm{SO}_{3}$ yield from TG analysis while XRF analysis satisfied first order model respectively. An increase in $\mathrm{SO}_{3}$ conversion and yields was observed as the calcination temperature and time were increased both independently and simultaneously. The calcination temperature was found to have a stronger influence compared to the calcination time. Validation indicated agreement between experimental and predicted values with a regression value of $97.8 \%$, $97.77 \%$ and $97.67 \%$ for $\mathrm{SO}_{3}$ conversion, $\mathrm{SO}_{3}$ yield via TG and XRF analyses respectively. Based on the ANOVA, the $\mathrm{SO}_{3}$ yield via XRF produced the best model with $\mathrm{R}_{\text {pred }}^{2}$ of $91.98 \%$ while $\mathrm{SO}_{3}$ yield via $\mathrm{TG}$ analysis and $\mathrm{SO}_{3}$ conversion had $\mathrm{R}_{\text {pred }}^{2}$ of $79.99 \%$ and $78.01 \%$ respectively. Optimization of the production of $\mathrm{SO}_{3}$ was carried out and the optimal condition for $\mathrm{SO}_{3}$ conversion, $\mathrm{SO}_{3}$ yield via TG and XRF analyes were $90.11 \%, 91.67 \%$ and $75.81 \%$ respectively at an optimal calcination temperature of $877.43{ }^{\circ} \mathrm{C}$ and time of 155.04 minutes respectively.
\end{abstract}

Keywords: Calcination temperature and time; Conversion; Face central composite design; Sulphur trioxide; Yield.

\section{INTRODUCTION}

Sulphur trioxide is invisible odourless but corrosive gas which is considered as an environmental pollutant $[1,2]$. It can be produced in an industrial scale as a precursor to sulphuric acid which has numerous industrial applications. Sulphur trioxide is an essential reagent required in sulphonation reactions. Sulfonation and sulfation are major industrial chemical processes used to make a diverse range of products, including dyes and color intensifiers, pigments, medicinal, pesticides and organic intermediates [3]. The most common production route of $\mathrm{SO}_{3}$ is the catalytic oxidation of sulphur dioxide which is formed from the oxidation of sulphur containing fossil fuels and industrial processes that treats and produces sulfur containing compounds [4]. Several routes for the production of $\mathrm{SO}_{3}$, among which the decomposition of aluminium sulfate has been considered suitable from [5] research work in which the calcination of aluminum sulfate was achieved by heating at temperature between $700-900{ }^{\circ} \mathrm{C}$ and time interval $60-180$ minutes. Despite the high efficiency of the production of $\mathrm{SO}_{3}$ via catalytic oxidation of $\mathrm{SO}_{2}$, the high cost of catalyst maintainace as well as the corrosive nature of sulphur dioxide are some of 
its demerits [4]. The thermal decomposition of aluminum sulfate results in the yield of sulphur trioxide which can be influenced by the calcination temperature, time and particle size of the aluminium sulfate in which the particle size was considered to be constant.

Optimization is an essential technique employed in improving the existing condition of a process [6] such as sulphur trioxide $\left(\mathrm{SO}_{3}\right)$ production and can be achieved through the use of Response Surface Methodology (RSM). The optimization involves either variation of a given parameter per unit time while the other parameter is held constant using RSM. Its techniques can be employed to establish functional relationships between responses of interest and some inputs [7] and based on their relationships, the dependent variables can be used to predict responses that can be compared with the experimental values [8]. The use of RSM cannot be overemphasized as it assists in the evaluation of several parameters simultaneously with their interactions by limiting the number of an experiment to be conducted, as well as optimize process parameters and estimation of interactions [9, 10]. Central Composite Design (CCD) is amongst one of the several techniques of RSM employed to design experimental procedures which have the advantage of screening a wide range of parameters as well as evaluating single variable/ cumulative effect of the variables to response [11]. It can also determine the number of the experiment to be able to evaluate for optimization of variables and responses [12] and has been found to widely used for the optimization techniques for calcination processes to produce significantly better models compared to other models [13].

An understanding of the interaction of the factors is essential in evaluating their relationship because their interactions are difficult to be determined using the one-factor-at-a-time approach [14]. The three stages in implementing response surface techniques include the design of experiment i.e. Box- Behnken or Central Composite Design (CCD), development of a model equation through statistical and regression analysis and finally optimization of parameters via model equation [15]. RSM has found applications in numerous experimental designs ranging from palm oil transesterification [16], extraction processes [8], drilling process [17], biodiesel production [18], prediction of blended cement properties $[19,20,21]$ and decomposition as well as other areas of engineering.
The aim of this paper is to investigate the effect of aluminum sulfate calcination temperature and time on the production of $\mathrm{SO}_{3}$ through response surface methodology using central composite design (CCD) and interactions studied. The comparison of the $\mathrm{SO}_{3}$ yields via TG and XRF techniques and $\mathrm{SO}_{3}$ conversion to ascertain which produces the best yield. It also involves optimization of the process conditions for the production of $\mathrm{SO}_{3}$ from the decomposition of aluminium sulfate derived from kaolin.

\section{EXPERIMENTAL DESIGN}

The summary of the design for responses; Sulphur trioxide conversion and yield estimation for $\mathrm{XRF}$ and TG values with calcination temperature and time as factors. The following parameters were chosen as independent variables: calcination temperature $\left(800{ }^{\circ} \mathrm{C}, 850{ }^{\circ} \mathrm{C}, 900{ }^{\circ} \mathrm{C}\right)$, while the calcination time (60 $\mathrm{min}, 120 \mathrm{~min}, 180 \mathrm{~min}$ ). Face central composite factorial design (3 level 2 factors) with 9 runs ( 1 block) (design expert 6.0) where -1 denotes low value of the independent variable $\left(800{ }^{\circ} \mathrm{C}, 60 \mathrm{~min}\right), 0$ used for the medium value $\left(850{ }^{\circ} \mathrm{C}, 120 \mathrm{~min}\right)$ and the high value $(900$ ${ }^{\circ} \mathrm{C}, 180 \mathrm{~min}$ ) were employed to investigate the effect of the above factors on the responses. A model was fitted to the response surface generated by the experiment.

$$
\begin{aligned}
& Y_{k}=f(\text { Calcination temperature, } \\
& \text { Calcination time })
\end{aligned}
$$

Design-Expert 6.0.8 software was employed to analyze the best fit data and to estimate the optimal value of the factors considered. RSM was used to determine the optimal process parameters to obtain maximum $\mathrm{SO}_{3}$ content. $\mathrm{CCD}$ at 3 levels, 2 factors was selected as independent variables and the interaction of variables were estimated. 9 runs were carried out to fit the general model of equation (1) and to obtain economically optimum conditions for the $\mathrm{SO}_{3}$ removal efficiency.

$$
Y=\beta_{0}+\sum_{i=1}^{k} \beta_{i} x_{i}+\sum_{i=1}^{k} \beta_{i} x_{i}^{2}+\sum_{i=1(i \neq j)}^{k} \beta_{i j} x_{i} x_{j},
$$

Where $Y$ is the $\mathrm{SO}_{3}$ yield, $\beta_{o}$ is the coefficient constant, $\beta_{i}$ is the linear coefficient, $\beta_{i i}$ quadratic coef- 
ficient effect, $\beta_{i j}$ is the interaction coefficient effect and $\mathrm{X}_{\mathrm{i}} \mathrm{X}_{\mathrm{j}}$ is the coded values of variable $i$ and $j$ respectively. $\mathrm{Y}_{1}, \mathrm{Y}_{2}, \mathrm{Y}_{3}$ denotes $\mathrm{SO}_{3}$ conversion, $\mathrm{SO}_{3}$ yield via TG and XRF analyses respectively. $\mathrm{X}_{1}$ is the calcination temperature and $\mathrm{X}_{2}$ is calcination time.

Table 1 indicates the experimental results for the determination of the $\mathrm{SO}_{3}$ content via Thermogravimetric (TG) analysis and X-ray Fluorescence (XRF) analysis obtained from the calcination of alum derived kaolin to investigate its effect of calcination temperature and time on the $\mathrm{SO}_{3}$ formation. The statistical analysis of the results was carried out by ANOVA to evaluate the model and its parameters were tabulated in Table 2 .

The statistical significance was achieved by the Ftest of the experimental result obtained. The model terms were selected or rejected based on the probability value with $95 \%$ confidence level. Then, the response surface contour plots are generated to visualize the individual and the interactive effects of the variables.

Table 1 - Experimental Design and Results

\begin{tabular}{|c|c|c|c|c|c|}
\hline Run & $\operatorname{Temp}{ }^{\circ} \mathrm{C}, \mathrm{X}_{1}$ & Time min, $X_{2}$ & Conversion $\%, Y_{1}$ & $\mathrm{SO}_{3 \mathrm{TGA}} \%, \mathrm{Y}_{2}$ & $\mathrm{SO}_{3 \mathrm{XRF}} \%, \mathrm{Y}_{3}$ \\
\hline 1 & 800 & 60 & 8.30 & 7.55 & 6.33 \\
\hline 2 & 800 & 120 & 12.60 & 12.97 & 8.63 \\
\hline 3 & 800 & 180 & 16.97 & 17.46 & 11.59 \\
\hline 4 & 850 & 60 & 48.55 & 49.95 & 25.62 \\
\hline 5 & 850 & 120 & 68.29 & 70.25 & 45.91 \\
\hline 6 & 850 & 180 & 80.16 & 82.47 & 57.28 \\
\hline 7 & 900 & 60 & 97.40 & 94.44 & 93.75 \\
\hline 8 & 900 & 120 & 97.40 & 97.26 & 95.49 \\
\hline 9 & 900 & 180 & 97.40 & 97.36 & 97.23 \\
\hline
\end{tabular}

Face central composite design was employed and the factors required include calcination temperature $\left(\mathrm{X}_{1}\right)$ and time $\left(\mathrm{X}_{2}\right)$ with the responses; $\mathrm{SO}_{3}$ conversion $\left(\mathrm{Y}_{1}\right)$ and $\mathrm{SO}_{3}$ yield from $\mathrm{TG}\left(\mathrm{Y}_{2}\right)$ and $\mathrm{XRF}\left(\mathrm{Y}_{3}\right)$ analyses. The factors and the response variables were investigated and the effect of the various factors on the responses were determined using design expert 6.0.8. Results indicated that a quadratic equation was obtained for $\mathrm{SO}_{3}$ conversion and $\mathrm{SO}_{3}$ yield from TG analysis whereas $\mathrm{SO}_{3}$ yield from XRF analysis satisfied linear model:

$Y_{1}=-4037.45+8.67 X_{1}+0.86 X_{2}-$ $0.0045 X_{1}^{2}-0.000563 X_{2}^{2}-0.0072 X_{1} X_{2}$

$Y_{2}=-4663.90+10.172 X_{1}+0.79 X_{2}-$ $0.0055 X_{1}^{2}-0.00057 X_{2}^{2}-0.0058 X_{1} X_{2}$

$Y_{3}=-701.79+0.86 X_{1}+0.11 X_{2}$

The Equations (3) to (5) represent quantitative effect of the factor variables; calcination temperature and time $\left(\mathrm{X}_{1}, \mathrm{X}_{2}\right)$ and their interactions on the response; $\mathrm{SO}_{3}$ conversion and $\mathrm{SO}_{3}$ yield from $T G$ and $X R F$ values $\left(Y_{1}, Y_{2}, Y_{3}\right)$. The values of $X_{1}$ and $X_{2}$ were substituted in the equation to obtain the theoretical value of $Y_{1} Y_{2}$ and $Y_{3}$ respectively. Based on the experimental design and factor combination, linear model was found to be significant for $\mathrm{SO}_{3}$ via XRF analysis amongst other responses which were significant for quadratic models.

Table 2 indicates the analysis of variance (ANOVA) for $\mathrm{SO}_{3}$ conversion, $\mathrm{SO}_{3}$ yield from TG analysis and $\mathrm{SO}_{3}$ yield from XRF analysis, all gave $\mathrm{F}$ value for lack of fit was 2.34, 2.33 and 1.53 respectively which also confirms that the models are significant due to the fact that it has an insignificant lack of fit. Table 2 also indicates the model $\mathrm{F}$ values for $\mathrm{SO}_{3}$ conversion, $\mathrm{SO}_{3}$ yield for TG and $\mathrm{SO}_{3}$ yield for XRF are 62.54, 69.16 and 125.09 respectively, thus the models are significant implying that there is $0.01 \%$ possibility that the noise will be large.

Tables 3-5 indicate that the Predicted $\mathrm{R}^{2}$ value for the three responses were in logical conformity with the adjusted $\mathrm{R}^{2}$ value for determination of the 3 responses. The several models produced adequate precision ratios indicating a desirable signal which was greater than 4 [22]. 
Table 2 - ANOVA for Response Surface Quadratic Model Analysis of Variance for Conversion and Percentage $\mathrm{SO}_{3}$ Yield for XRF \& TG analyses with Central Composite Design CCD

\begin{tabular}{|c|c|c|c|c|c|}
\hline Source & Sum of Squares & DF & Mean Square & F Value & Prob $>$ F \\
\hline Model $Y_{1}$ & 11558.43 & 5 & 2311.69 & 62.54 & $<0.0001$ \\
\hline $\mathrm{X}_{1}$ & 10780.62 & 1 & 10780.62 & 291.65 & $<0.0001$ \\
\hline $\mathrm{X}_{2}$ & 270.41 & 1 & 270.41 & 7.32 & 0.0304 \\
\hline $\mathrm{X}_{1}{ }^{2}$ & 357.8 & 1 & 357.8 & 9.68 & 0.0171 \\
\hline $\mathrm{X}_{2}{ }^{2}$ & 11.35 & 1 & 11.35 & 0.31 & 0.5968 \\
\hline $\mathrm{X}_{1} \mathrm{X}_{2}$ & 18.79 & 1 & 18.79 & 0.51 & 0.4989 \\
\hline Residual & 258.75 & 7 & 36.96 & & \\
\hline Lack of Fit & 258.75 & 3 & 86.25 & 2.34 & 0.8240 \\
\hline Model $Y_{2}$ & 11567.17 & 1 & 2313.43 & 69.16 & $<0.0001$ \\
\hline $\mathrm{X}_{1}$ & 10506.86 & 1 & 10506.86 & 314.08 & $<0.0001$ \\
\hline $\mathrm{X}_{2}$ & 342.77 & 1 & 342.77 & 10.25 & 0.015 \\
\hline $\mathrm{X}_{1}{ }^{2}$ & 512.73 & 1 & 512.73 & 15.33 & 0.0058 \\
\hline $\mathrm{X}_{2}{ }^{2}$ & 17.68 & 1 & 17.68 & 0.53 & 0.4908 \\
\hline $\mathrm{X}_{1} \mathrm{X}_{2}$ & 12.22 & 7 & 12.22 & 0.37 & 0.5647 \\
\hline Residual & 234.17 & 3 & 33.45 & & \\
\hline Lack of Fit & 234.17 & 2 & 58.06 & 2.33 & 0.8240 \\
\hline Model $\mathrm{Y}_{3}$ & 11531.76 & 1 & 11259.73 & 244.29 & $<0.0001$ \\
\hline $\mathrm{X}_{1}$ & 11259.73 & 1 & 272.03 & 5.09 & 0.0355 \\
\hline $\mathrm{X}_{2}$ & 272.03 & 10 & 46.09 & & \\
\hline Residual & 460.93 & 6 & 76.82 & 1.53 & 0.1176 \\
\hline Lack of Fit & 460.93 & & & & \\
\hline
\end{tabular}

Table 3 - Model Summary Statistics/ Sequential Model Sum of Squares for CCD for $\mathrm{SO}_{3}$ Conversion

\begin{tabular}{|c|c|c|c|c|}
\hline Source & Linear & 2FI & Quadratic & Cubic \\
\hline Sum of Squares & 11051.04 & 18.79 & $\mathbf{4 . 8 8 . 6 0}$ & 247.98 \\
\hline DF & 2 & 1 & $\mathbf{2}$ & 2 \\
\hline Mean square & 5525.52 & 18.79 & $\mathbf{2 4 4 . 3}$ & 123.99 \\
\hline F value & 72.12 & 0.23 & $\mathbf{6 . 6 1}$ & 57.54 \\
\hline Prob> F & $<0.0001$ & 0.6406 & $\mathbf{0 . 0 2 4 4}$ & $<0.0004$ \\
\hline Std. Dev. & 8.75 & 9.11 & $\mathbf{6 . 0 8}$ & 1.47 \\
\hline $\mathrm{R}^{2}$ & 0.9352 & 0.9368 & $\mathbf{0 . 9 7 8 1}$ & 0.9908 \\
\hline Adj. R $\mathrm{R}^{2}$ & 0.9222 & 0.9157 & $\mathbf{0 . 9 6 2 5}$ & 0.9978 \\
\hline Pred. $\mathrm{R}^{2}$ & 0.87173 & 0.752 & $\mathbf{0 . 7 8 0 1}$ & 0.8941 \\
\hline PRESS & 1516.96 & 2930.38 & $\mathbf{2 5 9 8 . 2 1}$ & 1251.95 \\
\hline & Suggested & & Suggested & Aliased \\
\hline
\end{tabular}

Authors [23] and [24] reported that a fitted model is said to be acceptable when the $\mathrm{R}^{2}$ is not less than $80 \%$ and greater than $75 \%$ respectively. In this study, the predicted values for developed models had a good correlation with the experimental results as shown in Table 3 indicated $\mathrm{R}^{2}$ values for $97.81 \%, 98.02 \%$ and $96.16 \%$ respectively while $\mathrm{R}^{2}$ adj value for $\mathrm{SO}_{3}$ conversion, $\mathrm{SO}_{3}$ yield via $\mathrm{TG}$ and $\mathrm{XRF}$ analyses were $96.25 \%, 96.60 \%$ and $95.39 \%$ respectively, indicating appropriateness of the developed model in predicting the $\mathrm{SO}_{3}$ conversion, $\mathrm{SO}_{3}$ yield via TG and XRF analyses for the two factors with $\mathrm{R}^{2}$ and $\mathrm{R}^{2}$ adj value close to unity. Authors [25] and
[26] stated that a better empirical model fit was obtained with the experimental data when the $\mathrm{R}^{2}$ value is close to unity and observed that a relatively high $\mathrm{R}^{2}$ value does not imply that the model is adequate, thus, [25] suggested that a $\mathrm{R}^{2}$ adj of above $90 \%$ is most appropriate to evaluate the model adequacy for the three responses which were closer to unity. Thus, indicating a good fit of the model to experimental results.

The analysis of variance showed the significant effect of the independent variables on the responses and determine the responses which were significantly affected by the various interactions. The following model terms $\mathrm{X}_{1}, \mathrm{X}_{2}, \mathrm{X}_{1}^{2}$ were 
considered significant while the model terms greater than 0.10 were considered not significant for experimental $\mathrm{SO}_{3}$ conversion and $\mathrm{SO}_{3}$ yield via TG analysis whereas, $\mathrm{SO}_{3}$ yield via XRF analysis showed that only the linear model terms $\mathrm{X}_{1}$, $\mathrm{X}_{2}$ were considered significant. The calcination temperature, $\left(X_{1}\right)$ obtained a $F$ value of 291.65 , 314.08 and 244.29 , while for the calcination time $\left(\mathrm{X}_{2}\right)$ produced a $\mathrm{F}$ value of $7.32,10.25$ and 5.09 for the experimental $\mathrm{SO}_{3}$ conversion, $\mathrm{SO}_{3}$ yield for TG and XRF analyses respectively. The high $\mathrm{F}$ values are a strong indication that the effect of the calcination temperature is far more significant compared to the calcination time for all the models. The quadratic term of the temperature obtained a $F$ values of 9.68 and 15.33 respectively with $\mathrm{p}$ values falling within $\mathrm{p}<0.05$ or $\mathrm{p}<$ 0.10 respectively. The quadratic term of the calcination time as well as the product of the calcination temperature and time obtained low $\mathrm{F}$ values, thus indicating that their effect is insignificant for the first two responses. It could be concluded that both factors $\mathrm{X}_{1}$ and $\mathrm{X}_{2}$ significantly affected the three responses.

Table 4 - Model Summary Statistics/ Sequential Model Sum Of Squares for CCD for $\mathrm{SO}_{3}$ Yield with TG analysis

\begin{tabular}{|c|c|c|c|c|}
\hline Source & Linear & 2FI & Quadratic & Cubic \\
\hline Sum of Squares & 10849.63 & 12.22 & $\mathbf{7 0 5 . 3 2}$ & 227.42 \\
\hline DF & 2 & 1 & $\mathbf{2}$ & 2 \\
\hline Mean square & 5424.82 & 12.22 & $\mathbf{3 5 2 . 6 6}$ & 113.71 \\
\hline F value & 57 & 0.12 & $\mathbf{1 0 . 5 4}$ & 84.28 \\
\hline Prob> F & $<0.0001$ & 0.7401 & $\mathbf{0 . 0 0 7 7}$ & 0.0001 \\
\hline Std. Dev. & 9.76 & 10.22 & $\mathbf{5 . 7 8}$ & 1.16 \\
\hline $\mathrm{R}^{2}$ & 0.9194 & 0.9204 & $\mathbf{0 . 9 8 0 2}$ & 0.9994 \\
\hline Adj. $\mathrm{R}^{2}$ & 0.9032 & 0.8939 & $\mathbf{0 . 9 6 6}$ & 0.9986 \\
\hline Pred. R & 0.8403 & 0.6755 & $\mathbf{0 . 7 9 9 9}$ & 0.9336 \\
\hline PRESS & 1884.27 & 3829.56 & $\mathbf{2 3 6 1 . 5 1}$ & 783.86 \\
\hline & Suggested & & Suggested & Aliased \\
\hline
\end{tabular}

From the experimental results, statistical testing was carried out employing Fishers test for ANOVA and the statistical significance of the second-order model indicated that the regression is statistically significant $(P<0.0001)$ for the first two responses while the third response statisti- cal data satisfied linear model; however, the lack of fit is not statistically significant at $99 \%$ confidence level, thus the residual variance for the models were insignificant $[27,28]$. The analysis of variance indicated significant effect of the independent variables on the responses.

Table 5 - Model Summary Statistics/ Sequential Model Sum of Squares for CCD for $\mathrm{SO}_{3}$ Yield with XRF values

\begin{tabular}{|c|c|c|c|c|}
\hline Source & Linear & 2FI & Quadratic & Cubic \\
\hline Sum of Squares & $\mathbf{1 1 5 3 1 . 7 6}$ & 0.79 & 197.1 & 248.28 \\
\hline DF & $\mathbf{2}$ & 1 & 2 & 2 \\
\hline Mean square & $\mathbf{5 7 6 5 . 8 8}$ & 0.79 & 98.55 & 124.14 \\
\hline F value & $\mathbf{1 2 5 . 0 9}$ & 0.015 & 2.62 & 42.08 \\
\hline Prob> F & $<\mathbf{0 . 0 0 0 1}$ & 0.9037 & 0.1412 & $<0.0007$ \\
\hline Std. Dev. & $\mathbf{6 . 7 9}$ & 7.15 & 6.13 & 1.72 \\
\hline $\mathrm{R}^{2}$ & $\mathbf{0 . 9 6 1 6}$ & 0.9616 & 0.9781 & 0.9988 \\
\hline Adj. R $\mathrm{R}^{2}$ & $\mathbf{0 . 9 5 3 9}$ & 0.9488 & 0.9624 & 0.997 \\
\hline Pred. R & $\mathbf{0 . 9 1 9 8}$ & 0.8478 & 0.7808 & 0.8571 \\
\hline PRESS & $\mathbf{9 6 2 . 1 2}$ & 1830.36 & 2628.47 & 1714.22 \\
\hline & Suggested & & & Aliased \\
\hline
\end{tabular}

Normal Probability and Predicted vs Actual Plots. Figures 1 (b), 2 (b) and 3 (b) also indicated that there is a strong relationship between the pre- dicted and actual values for $\mathrm{SO}_{3}$ conversion, $\mathrm{SO}_{3}$ yield for TG and XRF values respectively based on the results obtained. 

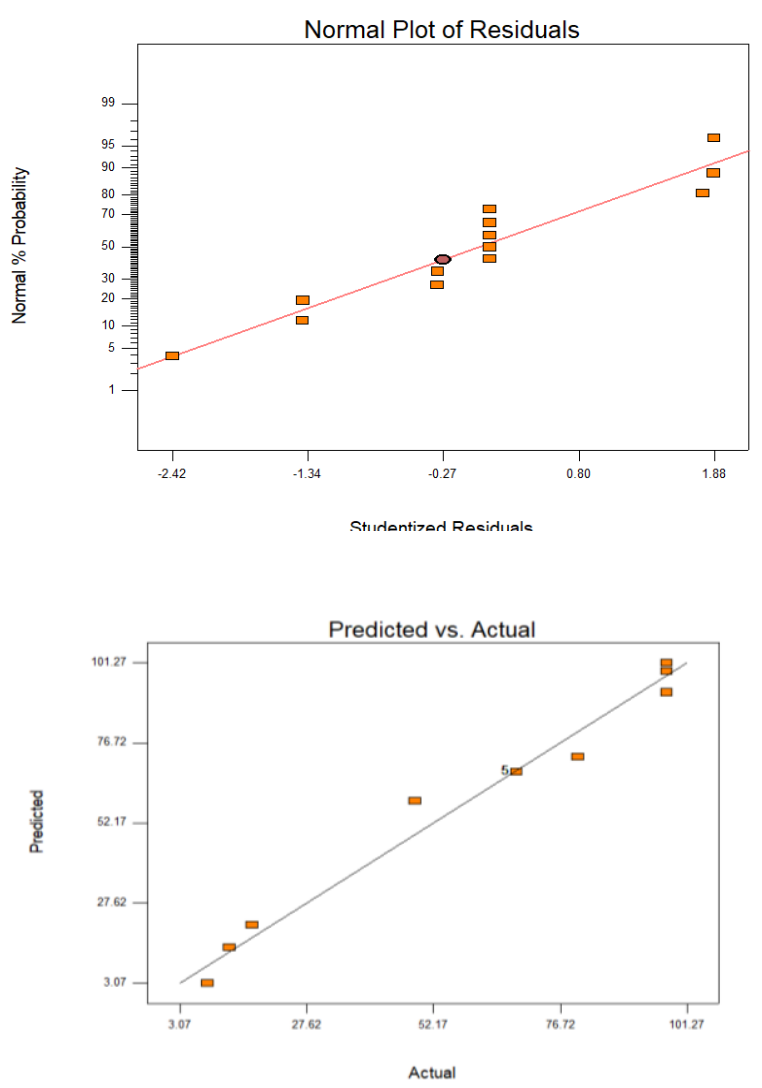

Figure 1 - (a) Normal Plot of residuals indicating significance of the model developed for $\mathrm{SO}_{3}$ conversion and (b) Predicted vs Actual plot of the model developed for $\mathrm{SO}_{3}$ conversion
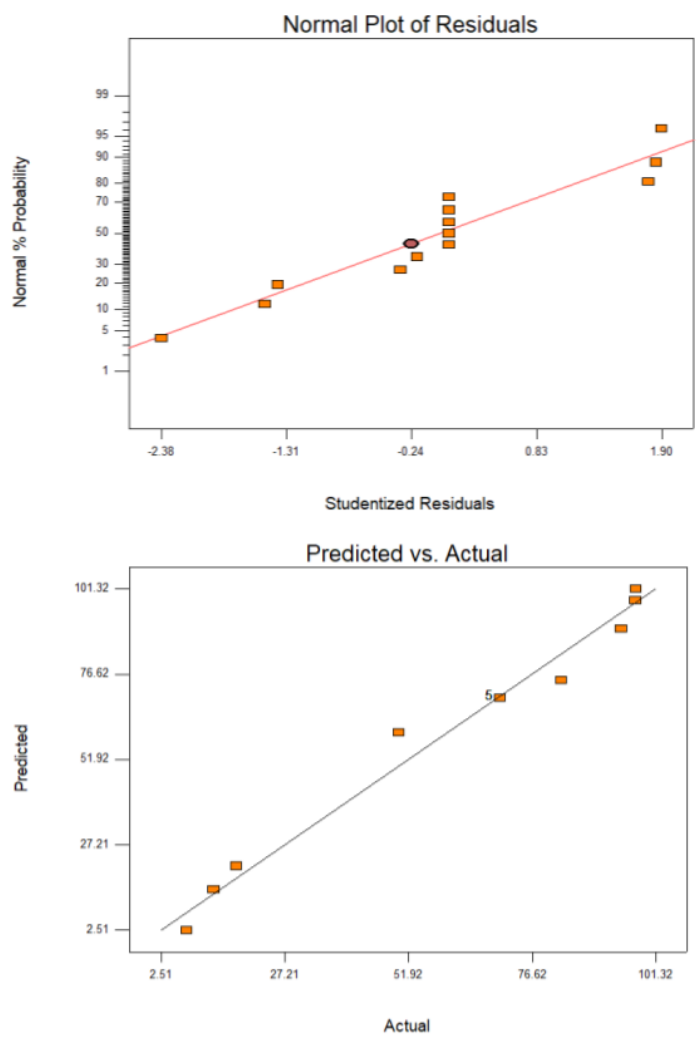

Figure 2 - (a) Normal Plot of residuals indicating significance of the model developed for $\mathrm{SO}_{3}$ yield with TG analysis and (b) Predicted vs Actual plot of the model developed for $\mathrm{SO}_{3}$ yield with $\mathrm{TG}$ analysis
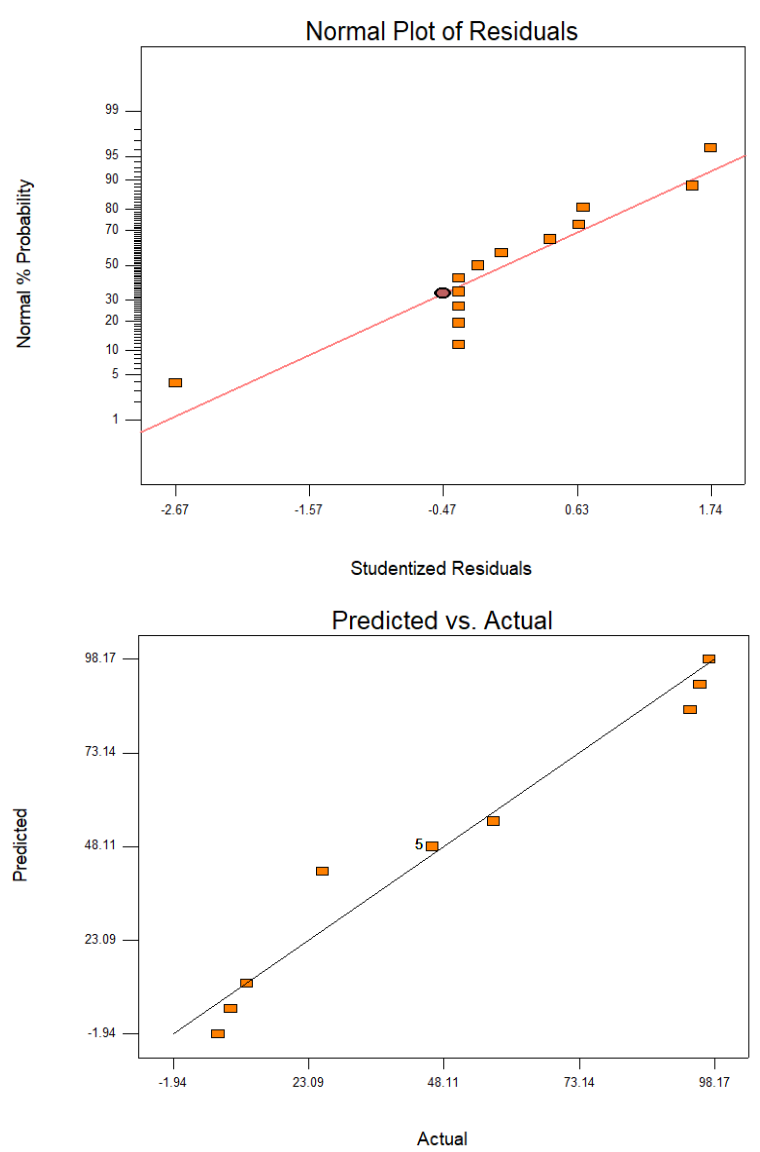

Figure 3 - (a) Normal Plot of residuals indicating significance of the model developed for $\mathrm{SO}_{3}$ yield with XRF and (b) Predicted vs Actual plot of the model developed for $\mathrm{SO}_{3}$ yield with XRF

It could be inferred that the predicted model obtained from the Design Expert software was significantly adequate in predicting $\mathrm{SO}_{3}$ conversion and $\mathrm{SO}_{3}$ yield for TG and XRF values respectively. Tables 6-8 illustrate the predicted values, actual values and residual errors of $\mathrm{SO}_{3}$ conversion and $\mathrm{SO}_{3}$ yield via $\mathrm{TG}$ and XRF analyses respectively.

Table 6 - Diagnotistic Case Statistics for $\mathrm{SO}_{3}$ Conversion

\begin{tabular}{|c|c|c|c|c|}
\hline $\begin{array}{c}\text { Temp } \\
{ }^{\circ} \mathrm{C}\end{array}$ & $\begin{array}{c}\text { Time } \\
\text { min }\end{array}$ & $\begin{array}{c}\text { Actual } \\
\text { value \% }\end{array}$ & $\begin{array}{c}\text { Predicted } \\
\text { Value \% }\end{array}$ & $\begin{array}{c}\text { Resid } \\
\text { ual \% }\end{array}$ \\
\hline 800 & 60 & 8.3 & 3.07 & 5.23 \\
\hline 800 & 120 & 12.6 & 13.97 & -1.37 \\
\hline 800 & 180 & 16.97 & 20.83 & -3.86 \\
\hline 850 & 60 & 48.55 & 59 & -10.45 \\
\hline 850 & 120 & 68.29 & 67.74 & 0.55 \\
\hline 850 & 180 & 80.16 & 72.43 & 7.73 \\
\hline 900 & 60 & 97.4 & 92.18 & 5.22 \\
\hline 900 & 120 & 97.4 & 98.75 & -1.35 \\
\hline
\end{tabular}


Table 7 - Diagnotistic Case Statistics for $\mathrm{SO}_{3}$ Yield via TG Analysis

\begin{tabular}{|c|c|c|c|c|}
\hline $\begin{array}{c}\text { Temp } \\
{ }^{\circ} \mathbf{C}\end{array}$ & $\begin{array}{c}\text { Time } \\
\text { min }\end{array}$ & $\begin{array}{c}\text { Actual } \\
\text { value \% }\end{array}$ & $\begin{array}{c}\text { Predicted } \\
\text { Value \% }\end{array}$ & $\begin{array}{c}\text { Re- } \\
\text { sidual } \\
\text { \% }\end{array}$ \\
\hline 800 & 60 & 7.55 & 2.51 & 5.04 \\
\hline 800 & 120 & 12.97 & 14.35 & -1.38 \\
\hline 800 & 180 & 17.46 & 21.12 & -3.66 \\
\hline 850 & 60 & 49.95 & 59.73 & -9.78 \\
\hline 850 & 120 & 70.25 & 69.82 & 0.43 \\
\hline 850 & 180 & 82.47 & 74.85 & 7.62 \\
\hline 900 & 60 & 94.44 & 89.7 & 4.74 \\
\hline 900 & 120 & 97.26 & 98.04 & -0.78 \\
\hline
\end{tabular}

Table 8 - Diagnotistic Case Statistics for $\mathrm{SO}_{3}$ Yield via XRF Analysis

\begin{tabular}{|c|c|c|c|c|}
\hline $\begin{array}{c}\text { Temp } \\
{ }^{\circ} \mathbf{C}\end{array}$ & $\begin{array}{c}\text { Time } \\
\text { min }\end{array}$ & $\begin{array}{c}\text { Actual } \\
\text { value \% }\end{array}$ & $\begin{array}{c}\text { Predicted } \\
\text { Value \% }\end{array}$ & $\begin{array}{c}\text { Re- } \\
\text { sidual } \\
\text { \% }\end{array}$ \\
\hline 800 & 60 & 6.33 & -1.94 & 8.27 \\
\hline 800 & 120 & 8.63 & 4.79 & 3.84 \\
\hline 800 & 180 & 11.59 & 11.53 & 0.064 \\
\hline 850 & 60 & 25.62 & 41.38 & -15.76 \\
\hline 850 & 120 & 45.91 & 48.11 & -2.2 \\
\hline 850 & 180 & 57.28 & 54.85 & 2.43 \\
\hline 900 & 60 & 93.75 & 84.7 & 9.05 \\
\hline 900 & 120 & 95.49 & 91.43 & 4.06 \\
\hline
\end{tabular}

Contour and 3D Plots. The correlation between the responses and the factors were further explained via contour and response surface plots. The diagnostic plots represented by Figures 4-6 employed to estimate the adequacy of the regression model which shows the response plots (3D) and the contour plots for the effect of factors $\mathrm{X}_{1}$ (calcination temperature), $\mathrm{X}_{2}$ (calcination time) on the first response $\mathrm{Y}_{1}\left(\mathrm{SO}_{3}\right.$ conversion), second response $\mathrm{Y}_{2} \quad \mathrm{SO}_{3}$ yield with $\mathrm{TG}$ analysis $)$ and third response $\mathrm{Y}_{3}\left(\mathrm{SO}_{3}\right.$ yield with $\mathrm{XRF}$ analysis) respectively. The response surface curves illustrate the interaction between the factors and determination of the optimal level of the factors for maximum response. The non-parabolic nature of contours implies no significant interaction between both factors [29] as observed in Figure 6.

The calcination temperature and time both caused an increase in the $\mathrm{SO}_{3}$ conversion and yield \% when their values were increased from lower level to higher level as observed from the 3D surface plots. The plotted response surface curves were employed to elucidated the interaction of the factors and to determine the optimal level of each factor for a maximum response. From the predictive model, an increase in the calcination temperature from $800-900{ }^{\circ} \mathrm{C}$ at constant time of 60,120 and 180 minutes led to a significant increase in the $\mathrm{SO}_{3}$ conversion respectively as illustrated in Figure 7.
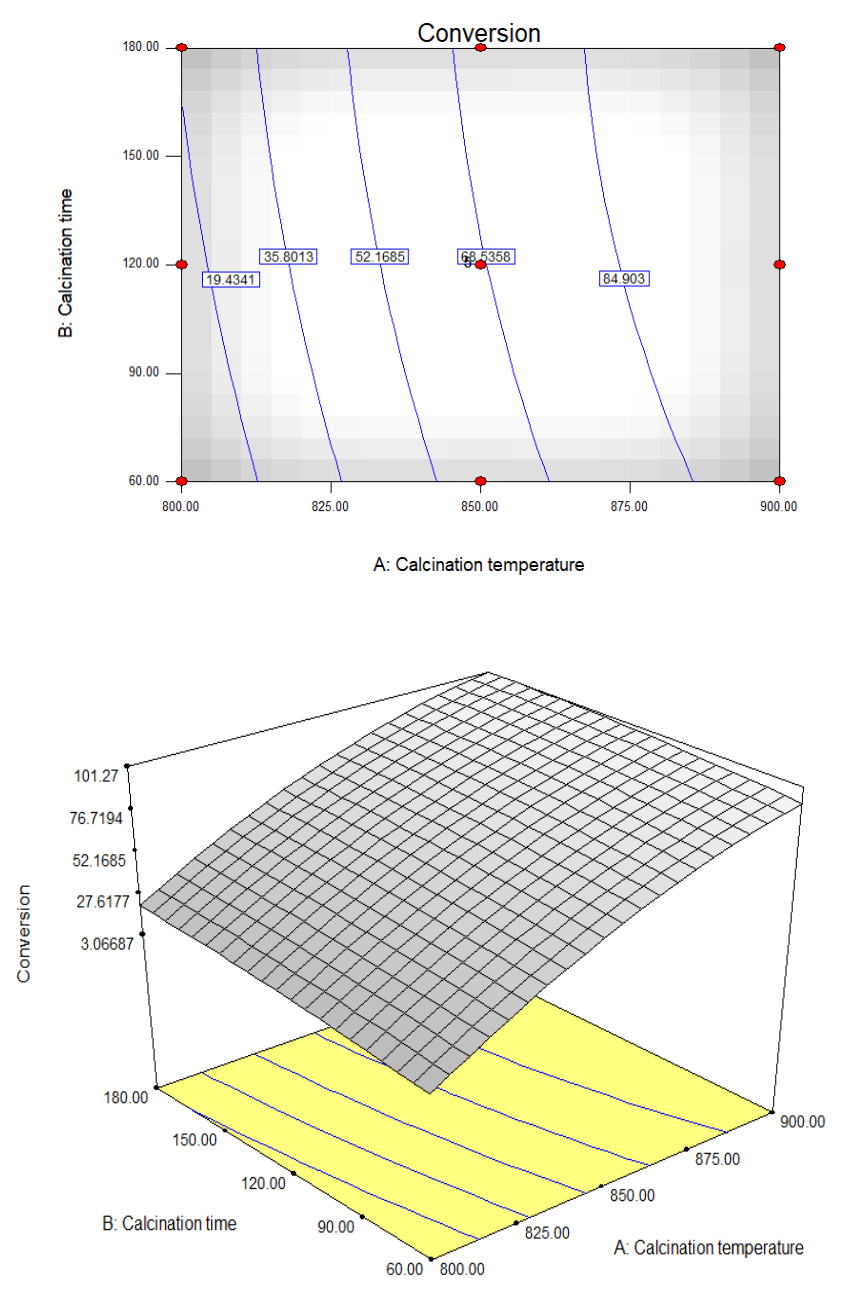

Figure 4 - Response surface plot (Contour and $3 \mathrm{D}$ surface) showing the effect of different factors $\left(X_{1}\right.$ : Calcination temperature, $X_{2}$ : calcination time) for $\mathrm{SO}_{3}$ yield with $\mathrm{TG}$ analysis for quadratic model

Similar trends of an increase in the $\mathrm{SO}_{3}$ yield from TG and XRF analyses were observed as the calcination temperature was increased at constant times of 60,120 and 180 minutes illustrated in Figures 5-6 respectively. A significant increase in the $\mathrm{SO}_{3}$ yield via TG and XRF analyses was experienced as both factors were gradually increased. Similarly, an increase in the $\mathrm{SO}_{3}$ conversion was experienced as the calcination time was gradually increased from 60 to $180 \mathrm{~min}$ at constant calcination temperature of 800,850 and $900^{\circ} \mathrm{C}$. 

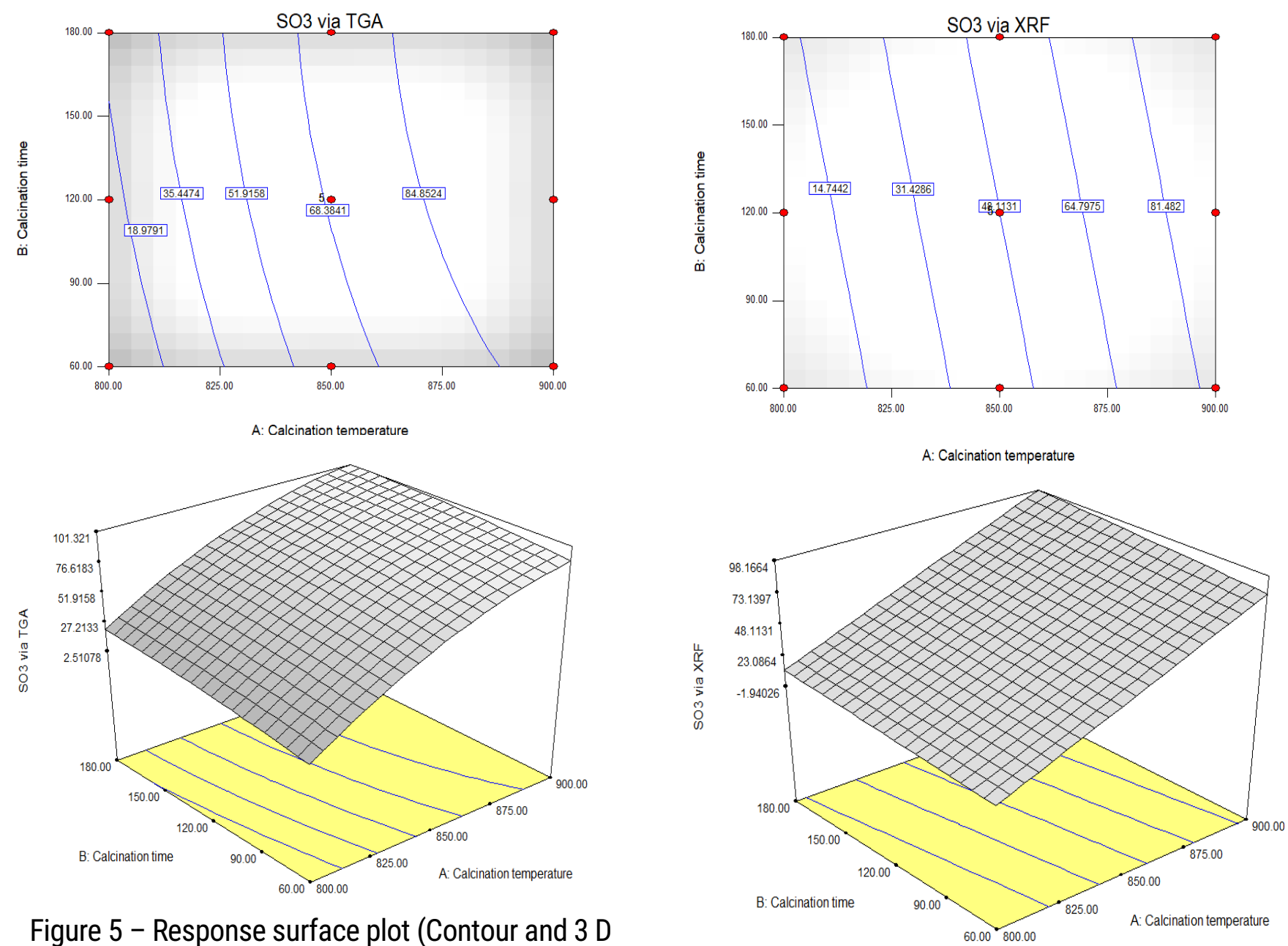

Figure 5 - Response surface plot (Contour and 3 D surface) showing the effect of different factors $\left(X_{1}\right.$ : Calcination temperature, $X_{2}$ : calcination time) for $\mathrm{SO}_{3}$ conversion for quadratic model

Figures 8 and 9 illustrate the effect of calcination time on the $\mathrm{SO}_{3}$ yield via $\mathrm{TG}$ and XRF analysis at various constant calcination temperature. From the predictive model for the determination of the $\mathrm{SO}_{3}$ via $\mathrm{TG}$ analysis, it could be observed that the $\mathrm{SO}_{3}$ yield increased as the calcination time progressed from 60-180 minutes while the calcination temperature was held constant at 800,825 , 850,875 and $900{ }^{\circ} \mathrm{C}$ respectively. The $\mathrm{SO}_{3}$ yield via TG analysis increased from $24.32-43.54 \%$, $49.93-65.67 \%$ as the calcination time progressed from 60-180 minutes at constant calcination temperature of 850 and $900{ }^{\circ} \mathrm{C}$ respectively. This increase in $\mathrm{SO}_{3}$ yield could be attributed to the increase in the duration of calcination stemming from the increase in kinetic energy gained by the molecules to overcome the activation energy resulting in increased $\mathrm{SO}_{3}$ yield.

Figure 6 - Response surface plot (Contour and 3D surface) showing the effect of different factors $\left(X_{1}\right.$ : Calcination temperature, $X_{2}$ : calcination time) for $\mathrm{SO}_{3}$ yield with XRF for quadratic model

Similar trend of an increase in the $\mathrm{SO}_{3}$ yield via $\mathrm{XRF}$ analysis as the calcination time progressed at constant calcination temperature of 800,825 , 850,875 and $900{ }^{\circ} \mathrm{C}$ respectively. The $\mathrm{SO}_{3}$ yields via XRF analysis were found to be higher compared to those obtained from TG analysis. The values of $\mathrm{SO}_{3}$ yield via XRF were also significantly close to $\mathrm{SO}_{3}$ conversion values at various calcination temperatures and time compared to those of $\mathrm{SO}_{3}$ yield via TG analysis. This could be attributed to the accuracy of the analyses of the $\mathrm{SO}_{3}$ yield. The increase in yield of $\mathrm{SO}_{3}$ from the decomposition of alum derived from kaolin clay could be attributed to the increase in amount of kinetic energy required to propagated the decomposition reaction as the temperature was increased or the calcination time progressed [29]. 

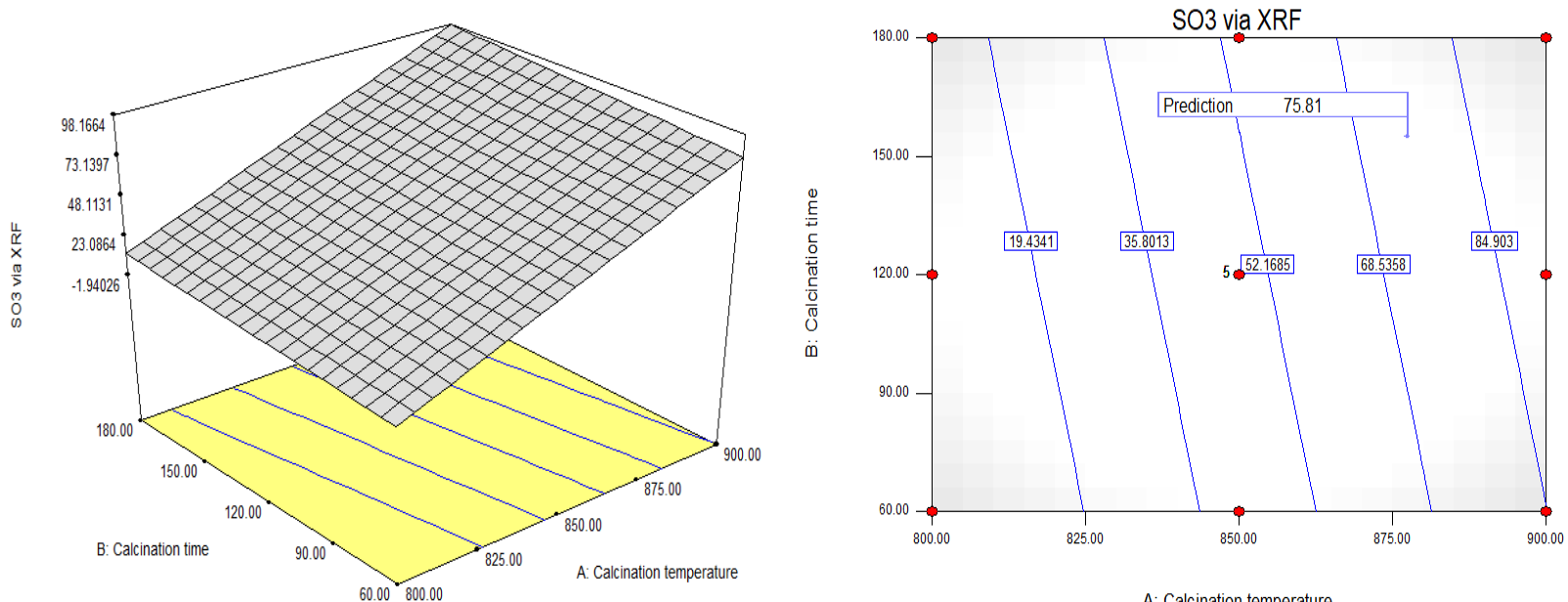

Figure 7 - Response surface plot (3D surface and Contour) indicating the optimal conditions $\left(\mathrm{X}_{1}\right.$ : Calcination temperature, $\mathrm{X}_{2}$ : calcination time) for $\mathrm{SO}_{3}$ conversion

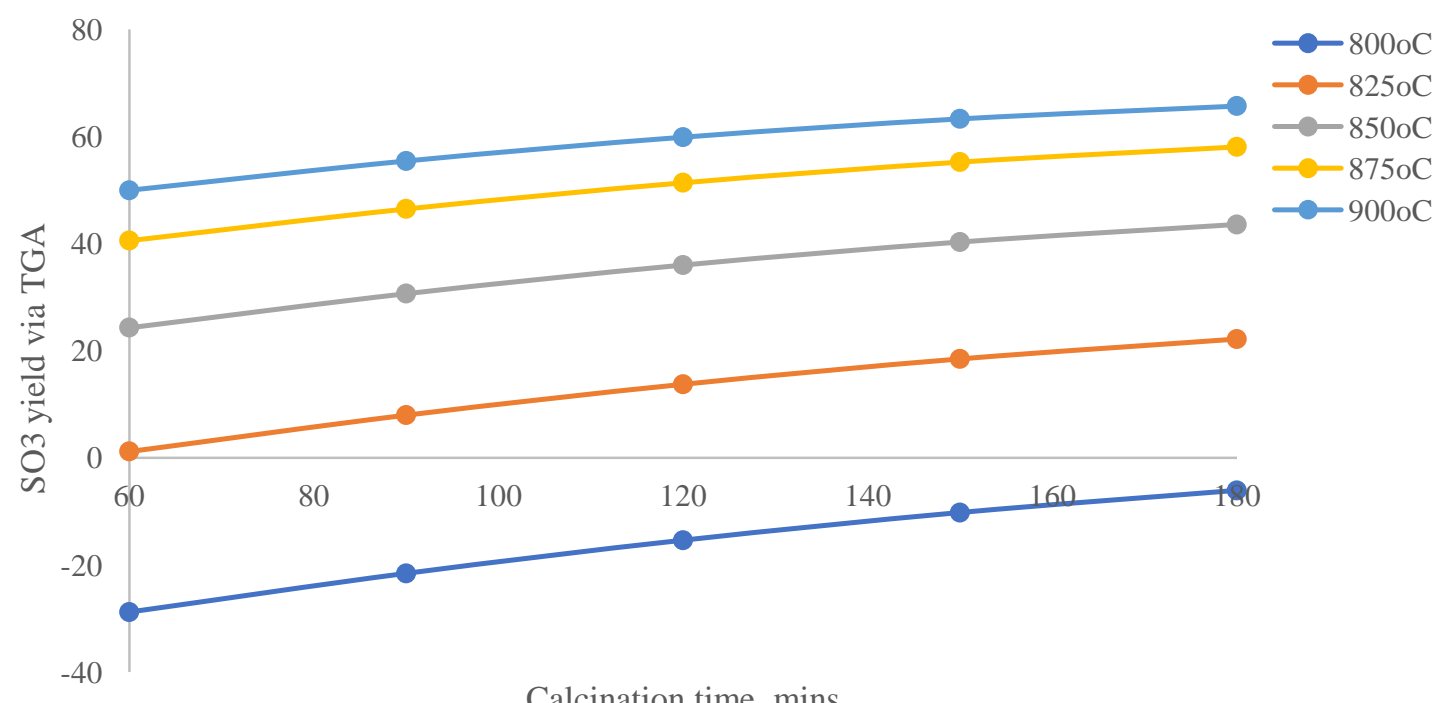

Figure 8 - Effect of calcination time on the $\mathrm{SO}_{3}$ yield via $\mathrm{TG}$ analysis at various calcination temperatures

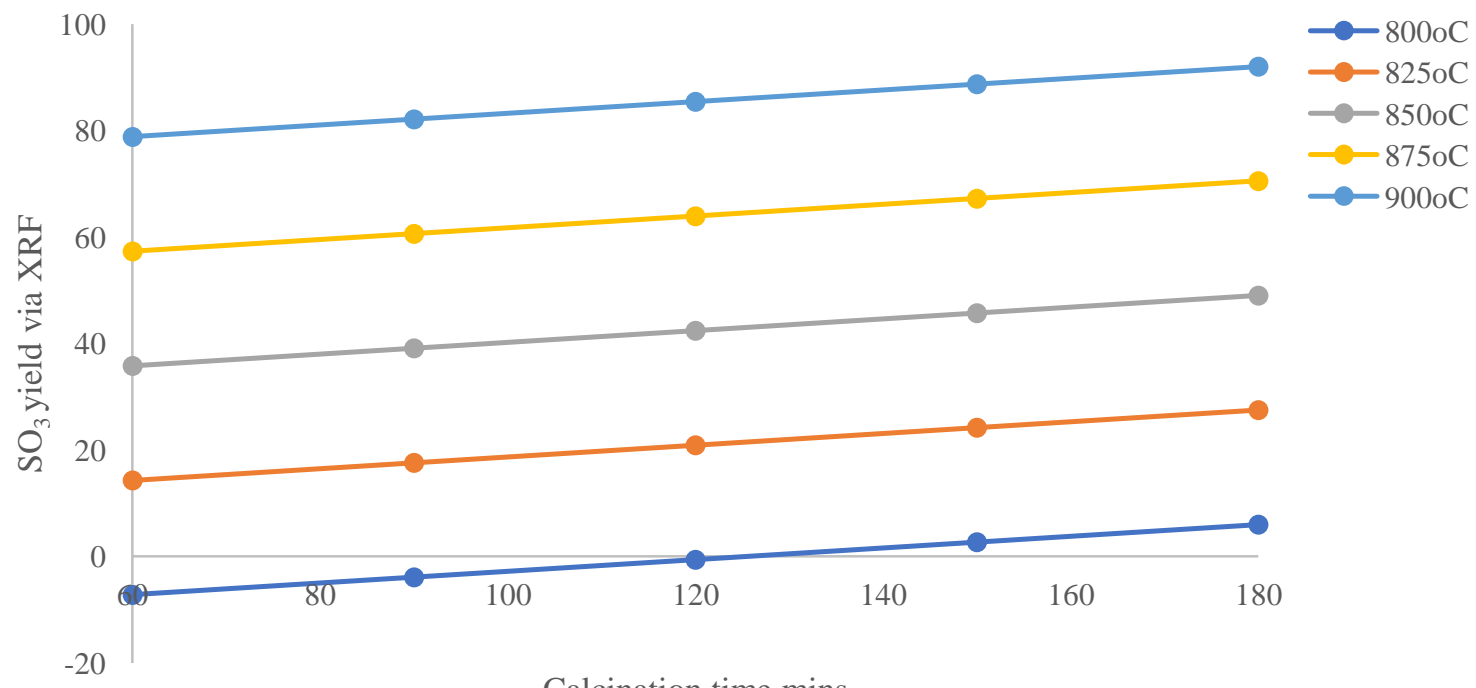

Calcination time mins

Figure 9 - Effect of calcination time on the $\mathrm{SO}_{3}$ yield via XRF at various calcination temperatures 


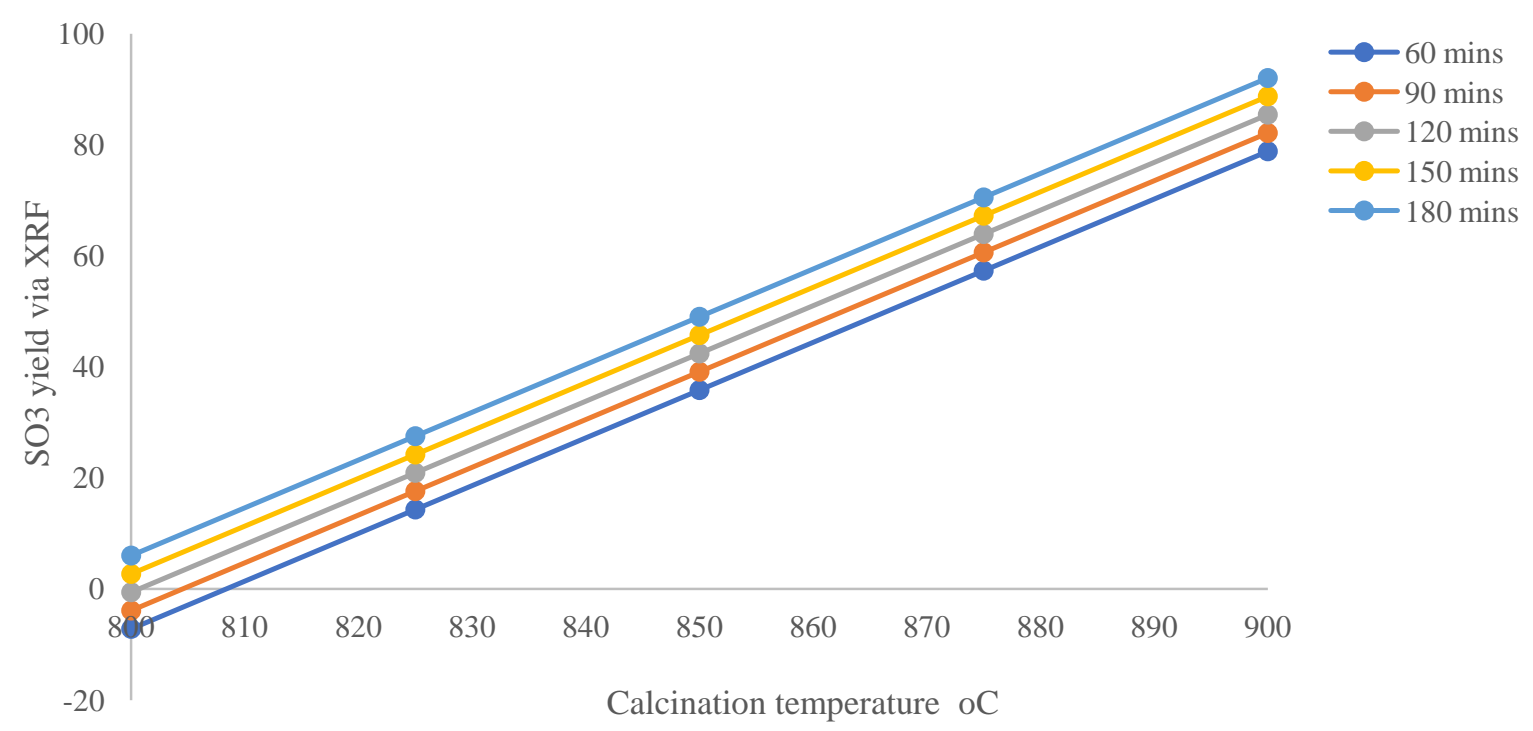

Figure 10 - Effect of calcination temperature on the $\mathrm{SO}_{3}$ yield via XRF at various calcination times

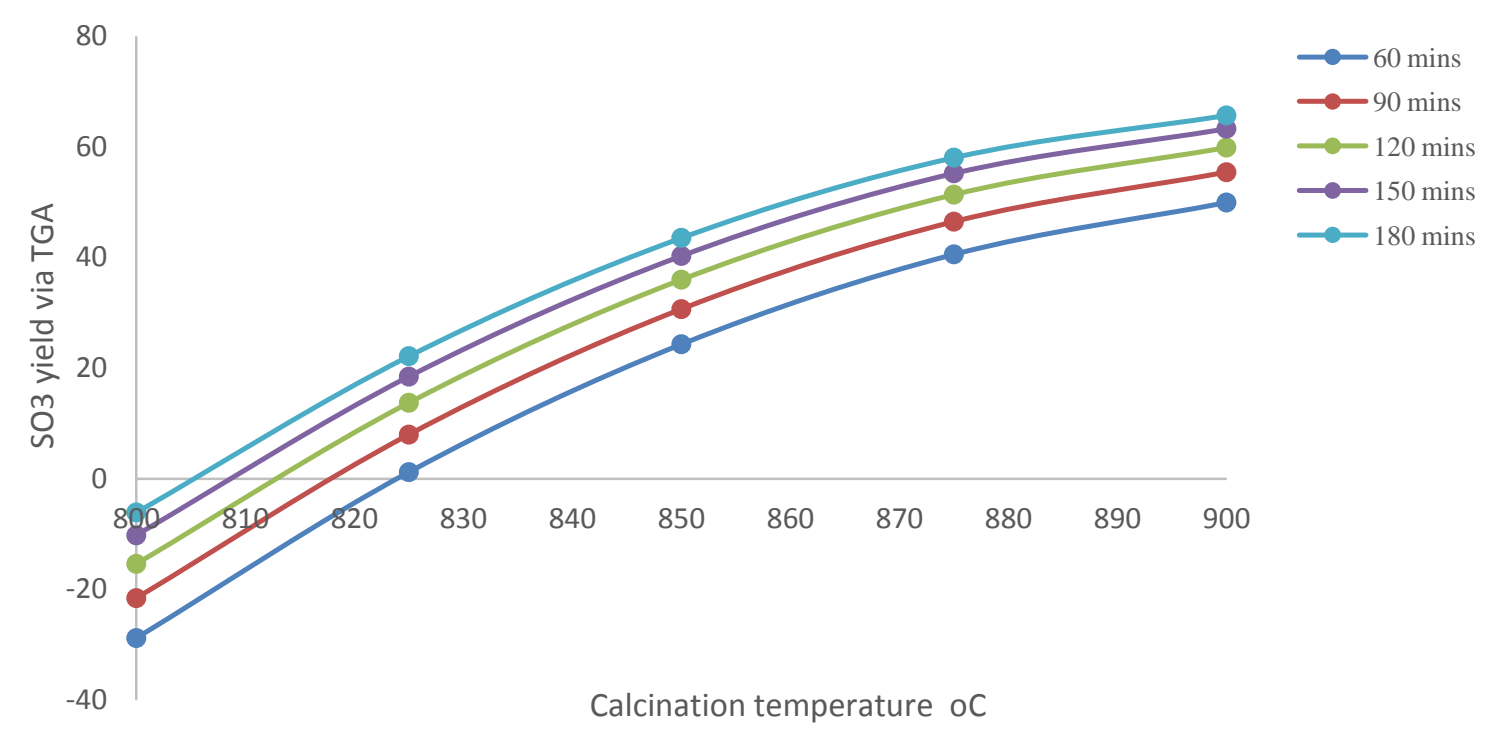

Figure 11 - Effect of calcination temperature on the $\mathrm{SO}_{3}$ yield via $\mathrm{TG}$ analysis at various calcination times

It could be observed in Figure 10 and 11, that as the calcination temperature was gradually increased from $800-900{ }^{\circ} \mathrm{C}$, there was a steady increase in the $\mathrm{SO}_{3}$ yield for both XRF and TG analyses respectively. On the other hand, the predictive model for the determination of the $\mathrm{SO}_{3}$ yield via XRF analysis, it could be seen that as the calcination time was held constant at 180 minutes and the calcination temperature was increased from $800-900{ }^{\circ} \mathrm{C}$, the $\mathrm{SO}_{3}$ yield via XRF increased from $6.01-92.01 \%$. Similar trend of an increase in the $\mathrm{SO}_{3}$ yield via XRF was observed for other calcination time at 60, 90, 120 and 150 minutes respectively.
Optimization. Optimization of the production of $\mathrm{SO}_{3}$ was conducted and the optimal conditions for optimal $\mathrm{SO}_{3}$ conversion of $90.11 \%, \mathrm{SO}_{3}$ yield via $\mathrm{TG}$ analysis of $91.67 \%$ and $\mathrm{SO}_{3}$ yield via XRF of $75.81 \%$ at an optimal calcination temperature of $877.43{ }^{\circ} \mathrm{C}$ and time of 155.04 minutes. Figures 12-13 indicated similar trend of an increase in the $\mathrm{SO}_{3}$ conversion and $\mathrm{SO}_{3}$ yield obtained via TG and XRF analyses as the calcination temperature and time of the aluminum sulfate was simultaneously increased as illustrated by the response surface plots. 

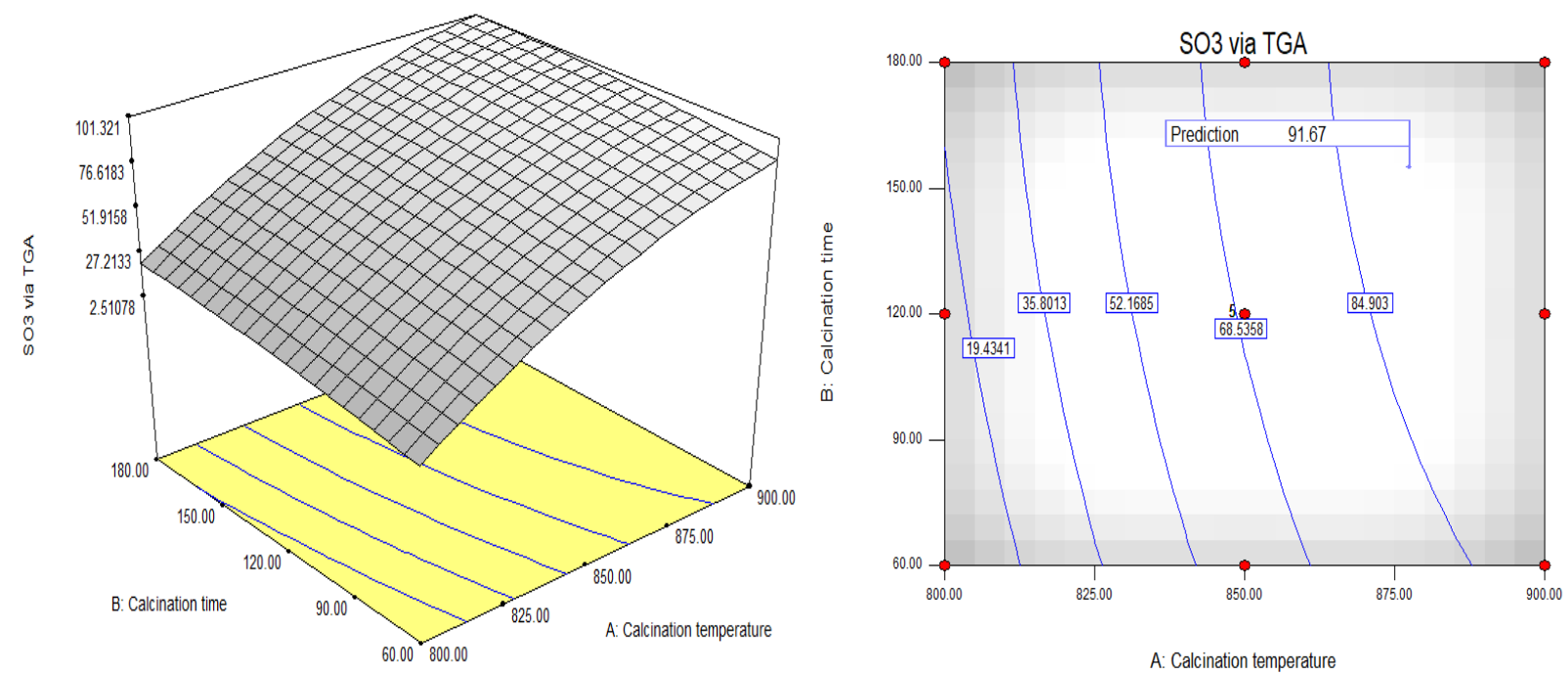

Figure 12 - Response surface plot (3D surface and Contour) indicating the optimal conditions $\left(\mathrm{X}_{1}\right.$ : Calcination temperature, $\mathrm{X}_{2}$ : calcination time) for $\mathrm{SO}_{3}$ yield via $\mathrm{TG}$ analysis respectively
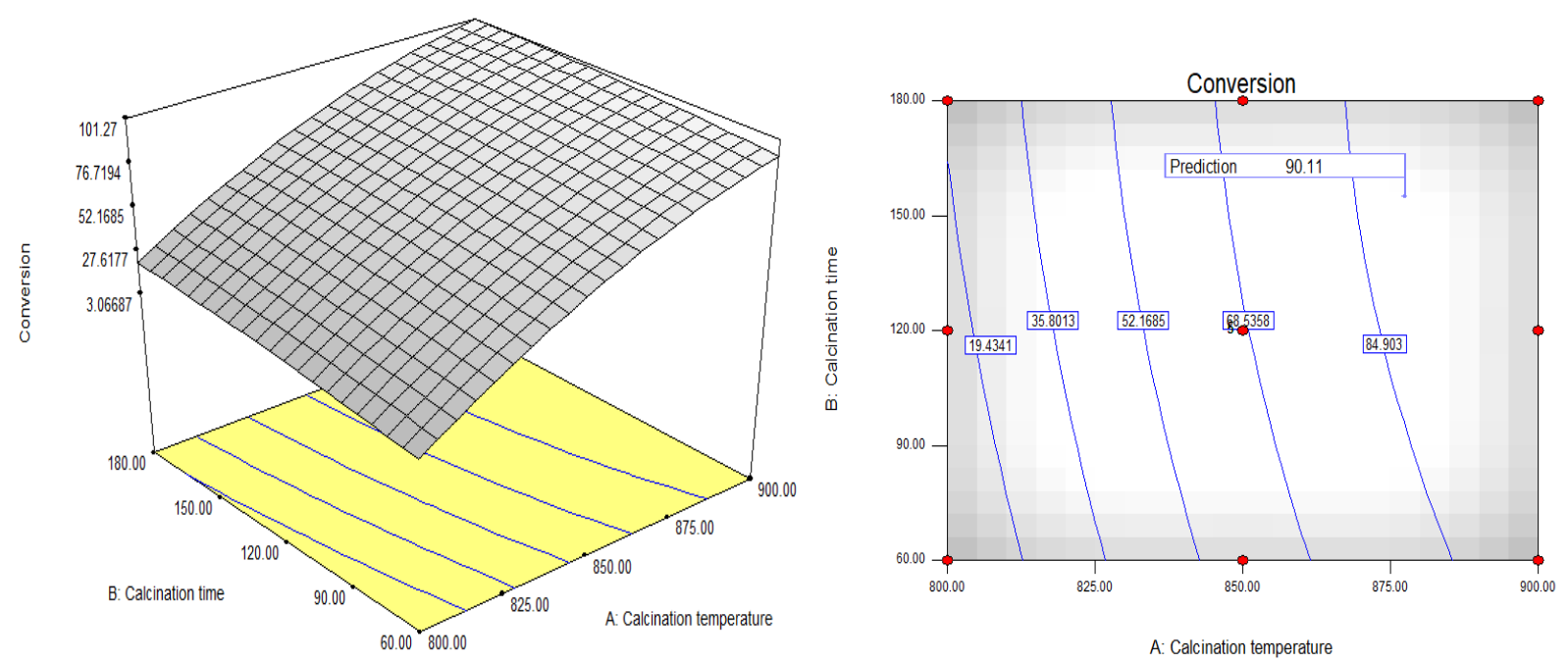

Figure 13 -Response surface plot (3D surface and Contour) indicating the optimal conditions $\left(\mathrm{X}_{1}\right.$ : Calcination temperature, $\mathrm{X}_{2}$ : calcination time) for $\mathrm{SO}_{3}$ yield via $\mathrm{XRF}$

\section{CONCLUSION}

An increase in the calcination temperature and time between $800-900{ }^{\circ} \mathrm{C}$ and $60-180$ minutes led to an increase in the $\mathrm{SO}_{3}$ conversion, $\mathrm{SO}_{3}$ yield via XRF and TG analyses respectively. Based on experimental results, an empirical relationship between the response and factors was obtained and found $\mathrm{SO}_{3}$ conversion and $\mathrm{SO}_{3}$ yield via TG analysis best suited with quadratic models whereas $\mathrm{SO}_{3}$ yield via XRF satisfied a linear model. The $\mathrm{SO}_{3}$ yields and conversion were established by the response surface and contour plots of the model-predicted responses. $\mathrm{The}_{3} \mathrm{SO}_{3}$ conversion and $\mathrm{SO}_{3}$ yields via TG and XRF analyses of $90.11 \%, 91.67 \%$ and $75.81 \%$ were obtained under optimal value of process parameters for calcination temperature of $877.43{ }^{\circ} \mathrm{C}$ and time of 155.04 minutes respectively. Analysis of variance for $\mathrm{SO}_{3}$ conversion and $\mathrm{SO}_{3}$ yields via $\mathrm{TG}$ and XRF analyses indicated a high coefficient of determination value for $\mathrm{SO}_{3}$ conversion and yields $\left(\mathrm{R}^{2}=97.8 \%, \mathrm{R}^{2}\right.$ adj $\left.=97.06 \%\right)(97.77 \%$, $\left.\mathrm{R}^{2}{ }_{\text {adj }}=97.03\right)$ and $\left(\mathrm{R}^{2}=97.67 \mathrm{R}^{2}{ }_{\mathrm{adj}}=97.06\right)$ respectively. Thus, a satisfactory agreement of the second-order regression and first order model with the experimental data for TG and XRF analyses respectively. The calcination temperature provided the most significant effect on the $\mathrm{SO}_{3}$ yields and conversion compared with calcination time. It was also observed from the ANOVA that $\mathrm{SO}_{3}$ yield via XRF gave the best model with $\left(\mathrm{R}^{2}\right.$ pred $=$ 91.98\%) compared to $\mathrm{SO}_{3}$ yield via $\mathrm{TG}$ analysis $\left(\mathrm{R}^{2}\right.$ pred $\left.=79.99 \%\right)$ and $\mathrm{SO}_{3}$ conversion $\left(\mathrm{R}^{2}\right.$ pred $\left.=78.01 \%\right)$ respectively. 


\section{ACKNOWLEDGEMENTS}

The authors wish to thank National Metallurgical Development Centre, Jos and the Department of Chemical Engineering of Ahmadu Bello University Zaria for providing infrastructure, facilities and their support to this research work.

\section{CONFLICT OF INTEREST}

The authors declared that they have no conflict of interest.

\section{REFERENCES}

1. Lerner, L. (2011). Small-Scale Synthesis of Laboratory Reagents with Reaction Modeling. New York: CRC Press.

2. Loerting, T., \& Liedl, K. R. (2000). Toward elimination of discrepancies between theory and experiment: The rate constant of the atmospheric conversion of SO3 to H2SO4. Proceedings of the National Academy of Sciences, 97(16), 8874-8878. doi: 10.1073/pnas.97.16.8874

3. Jadhav, Y., Deshpande, S., \& Sindhikar, A. (2018). Manufacturing of Sulphate castor oil (Turkey red oil) by the Sulphonation process. International Journal of Advanced Research in Science Engineering and Technology, 5(7), 6384-6389.

4. Dunn, J. P., Koppula, P. R., G. Stenger, H., \& Wachs, I. E. (1998). Oxidation of sulfur dioxide to sulfur trioxide over supported vanadia catalysts. Applied Catalysis B: Environmental, 19(2), 103-117. doi: 10.1016/s0926-3373(98)00060-5

5. Olubajo, O., Waziri, S., Aderemi, B. (2014). Kinetic of the decomposition of alum sourced from Kankara Kaolin. International Journal of Engineering Research and Technology, 3(2), 1629-1635.

6. Azami, M., Bahram, M., Nouri, S., \& Naseri, A. (2012). Central composite design for the optimization of removal of the azo dye, methyl orange, from waste water using fenton reaction. Journal of the Serbian Chemical Society, 77(2), 235-246. doi: 10.2298/jsc110315165a

7. Khuri, A., \& Mukhopadhyay, S. (2010). Response surface methodology. In E. J. Wegman, Y. H. Said, \& D. W. Scott (Eds.), Computational Statistics (pp. 128-149). Hoboken: John Wiley and Sons.

8. Said, Kh., \& Amin, M. (2015). Overview on the Response Surface Methodology (RSM) in Extraction Processes. Journal of Applied Science \& Process Engineering, 2(1), 8-17.

9. Hamzaoui, A. H., Jamoussi, B., \& M'nif, A. (2008). Lithium recovery from highly concentrated solutions: Response surface methodology (RSM) process parameters optimization. Hydrometallurgy, 90(1), 1-7. doi: 10.1016/j.hydromet.2007.09.005

10. Giménez, M., Blanes, P., Hunzicker, G., \& Garro, O. (2009). Application of a central composite design to the determination of inorganic and organic arsenic species in water by liquid chromatography-hydride generation- atomic absorption spectrometry. AFINIDAD, LXVI(540), 126-133.

11. Aybastıer, Ö., Şahin, S., Işık, E., \& Demir, C. (2011). Determination of total phenolic content in Prunella L. by horseradish peroxidase immobilized onto chitosan beads. Analytical Methods, 3(10), 2289. doi: 10.1039/c1ay05218g

12. Adeleke, O. A., Latiff, A. A. A., Saphira, M. R., Daud, Z., Ismail, N., Ahsan, A., ... Hijab, M. (2019). Locally Derived Activated Carbon From Domestic, Agricultural and Industrial Wastes for the Treatment of Palm Oil Mill Effluent. Nanotechnology in Water and Wastewater Treatment, 35-62. doi: 10.1016/b978-0-12-813902-8.00002-2

13. Olubajo, O. O., Makarfi, I. Y., \& Odey, O. A. (2019). Prediction of Loss on Ignition of Ternary Cement Containing Coal Bottom Ash and Limestone Using Central Composite Design. Path of Science, 5(8), 2010-2019. doi: 10.22178/pos.49-3

14. Elksibi, I., Haddar, W., Ben Ticha, M., gharbi, R., \& Mhenni, M. F. (2014). Development and optimisation of a non conventional extraction process of natural dye from olive solid waste using 
response surface methodology (RSM). Food Chemistry, 161, 345-352. doi:

10.1016/j.foodchem.2014.03.108

15. Ravikumar, K., Ramalingam, S., Krishnan, R., \& Balu, B. (2006). Application of response surface methodology to optimize the process variables for Reactive Red and Acid Brown dye removal using a novel adsorbent. Dyes and Pigments, 70(1), 18-26. doi: 10.1016/j.dyepig.2005.02.004

16. Wong, Y. C., Tan, Y. P., Taufiq-Yap, Y. H., \& Ramli, I. (2015). An Optimization Study for Transesterification of Palm Oil using Response Surface Methodology (RSM). Sains Malaysiana, 44(2), 281-290. doi: 10.17576/jsm-2015-4402-17

17. Chaudhary, G., Kumar, M., Verma, S., \& Srivastav, A. (2014). Optimization of Drilling Parameters of Hybrid Metal Matrix Composites Using Response Surface Methodology. Procedia Materials Science, 6, 229-237. doi: 10.1016/j.mspro.2014.07.028

18. Silva, G. F., Camargo, F. L., \& Ferreira, A. L. O. (2011). Application of response surface methodology for optimization of biodiesel production by transesterification of soybean oil with ethanol. Fuel Processing Technology, 92(3), 407-413. doi: 10.1016/j.fuproc.2010.10.002

19. Olubajo, O., Osha, O., Elnatafy, U., \& Adamu, H. (2017). A study on the physico-mechanical properties and the hydration of ordinary cement blended with limestone and coal bottom ash (Doctoral thesis); Abubakar Tafawa Balewa University Bauchi.

20. De Weerdt, K., Kjellsen, K. O., Sellevold, E., \& Justnes, H. (2011). Synergy between fly ash and limestone powder in ternary cements. Cement and Concrete Composites, 33(1), 30-38. doi: 10.1016/j.cemconcomp.2010.09.006

21. Myers, R., Montegomery, D., \& Anderson, C. (2009). Response Surface Methodology: Process and Product Optimization using Designed Experiment (3rd ed.). Hoboken: Wiley \& Sons Inc.

22. Koocheki, A., Taherian, A., Razavi, S., \& Bostan, A. (2009). Response surface methodology for optimization of extraction yield, viscosity, and hue and emulsion stability of mucilage extracted from Lepidium perfoliatum Seeds. Food Hydrocolloids, 23, 2369-2379.

23. Chauhan, B., \& Gupta, R. (2004). Application of statistical experimental design for optimization of alkaline protease production from Bacillus sp. RGR-14. Process Biochemistry, 39(12), 2115-2122. doi: 10.1016/j.procbio.2003.11.002

24. Abdulkarim Ikara, I. (2019). Predicting CBR Values of Black Cotton Soil Stabilized with Cement and Waste Glass Admixture Using Regression Model. American Journal of Traffic and Transportation Engineering, 4(1), 31. doi: 10.11648/j.ajtte.20190401.15

25. Zaibunnisa, A. H., Norashikin, S., Mamot, S., \& Osman, H. (2009). An experimental design approach for the extraction of volatile compounds from turmeric leaves (Curcuma domestica) using pressurised liquid extraction (PLE). LWT - Food Science and Technology, 42(1), 233-238. doi: 10.1016/j.lwt.2008.03.015

26. Arsenovic, M., Pezo, L., \& Radojevic, Z. (2012). Response surface method as a tool for heavy clay firing process optimization: Roofing tiles. Processing and Application of Ceramics, 6(4), 209-214. doi: $10.2298 /$ pac1204209a

27. Dutta, S., Ghosh, A., Moi, S. C., ... Saha, R. (2015). Application of Response Surface Methodology for Optimization of Reactive Azo Dye Degradation Process by Fenton's Oxidation. International Journal of Environmental Science and Development, 6(11), 818-823. doi: 10.7763/ijesd.2015.v6.705

28. Ramamoorthi, M., Rengasamy, M. (2015). Performance analysis of Mustard and Pongamia Methyl Ester Blends with diesel in CI engine. Journal of Chemical and Pharmaceutical Science, 4(4), 257259.

29. Dockery, G. (2017, April 24). The effect of temperature on activation energy. Retrieved from https://sciencing.com/effect-temperature-activation-energy-5041227.html 